\title{
PILGRIMAGE TOURISM MARKETING STRATEGY: SPECIAL REFERENCE TO DESTINATIONS OF UTTAR PRADESH
}

\author{
Mukesh Ranga ${ }^{1}$, \\ Priyanka Pradhan ${ }^{1}$ \\ IInstitute of Business Management, \\ CSJMU University, \\ Kanpur
}

\begin{abstract}
:
The effect of tourism as an industry is multidimensional. Tourism industry nourishes a country's economy, stimulates its improvement, supports restoration of cultural values and heritage and results in sustaining worldwide harmony. Religious tourism is an unexplored sector in which only a few researchers have initiated efforts in an organized manner. Religious tourism, however, is not only destination oriented. It can also imply attracting various segments of the market. Pilgrimage tourism is the kind of tourism that completely or strongly stimulates tourists for the accomplishment of their religious outlook. This research paper discusses the present scenario of Uttar Pradesh including tourism attractions, tourism services and types. The descriptive research method is used and the paper is systematized in three basic parts: first, an analysis of multidisciplinary literature which reconnoitres the existing data on the religious places; second, how government measures are used as marketing strategies; and at the end, the paper will present economic impacts along with opportunities facing the religious tourism in Uttar Pradesh.
\end{abstract}

\section{Keywords:}

religious tourism, marketing, opportunities, tourism, destination image.

\section{INTRODUCTION}

Mankind has an inherent wish to explore and seek the diverse world cultures. Tourism is an action dependent on three functioning components - discretionary income, leisure time and social sanctions permissive of travels (Smith, 1992). Religious tourism is an important and fast growing sector within the tourism industry. It is, at times, discussed as faith tourism, faith-based travel, pilgrimage tourism, Christian tourism, Muslim tourism, or any other 'travel' or 'tourism' associated with a religious denomination. Almost every type of tourism exists in India because of its diversity of cultures, festivals, religions etc. The existence of religious tourism in India is not sufficiently recognized, but there are many sites in India that fit under this category. 
Table 1. Religious Places of Uttar Pradesh

\begin{tabular}{|c|c|c|c|c|}
\hline Western UP & South West UP & Central UP & East UP & South East UP \\
\hline & (Bundelkhand) & (Awadh) & & \\
\hline \multicolumn{5}{|c|}{ Religious: Hinduism } \\
\hline Agra / Fatehpur Sikri & Chitrakoot & Ayodhya & Gorakhpur & Varanasi \\
\hline Mathura/ Vrindavan & & Kannauj & & Allahabad \\
\hline Hastinapur & & Faizabad & & Jaunpur \\
\hline \multirow[t]{4}{*}{ Garh Mukteshwar } & & & & Chandra \\
\hline & & & & Prabha/ \\
\hline & & & & Naugarh \\
\hline & & & & Sringverpur \\
\hline
\end{tabular}

Religious: Islamic

\begin{tabular}{cccc}
\hline Agra / Fatehpur Sikri & Kannauj & Varanasi & Jaunpur \\
\hline & & \\
\hline & Religious: Buddhist & \\
\hline Sankisa & Kushi Nagar & Sarnath \\
\hline
\end{tabular}

\section{Religious: Jain}

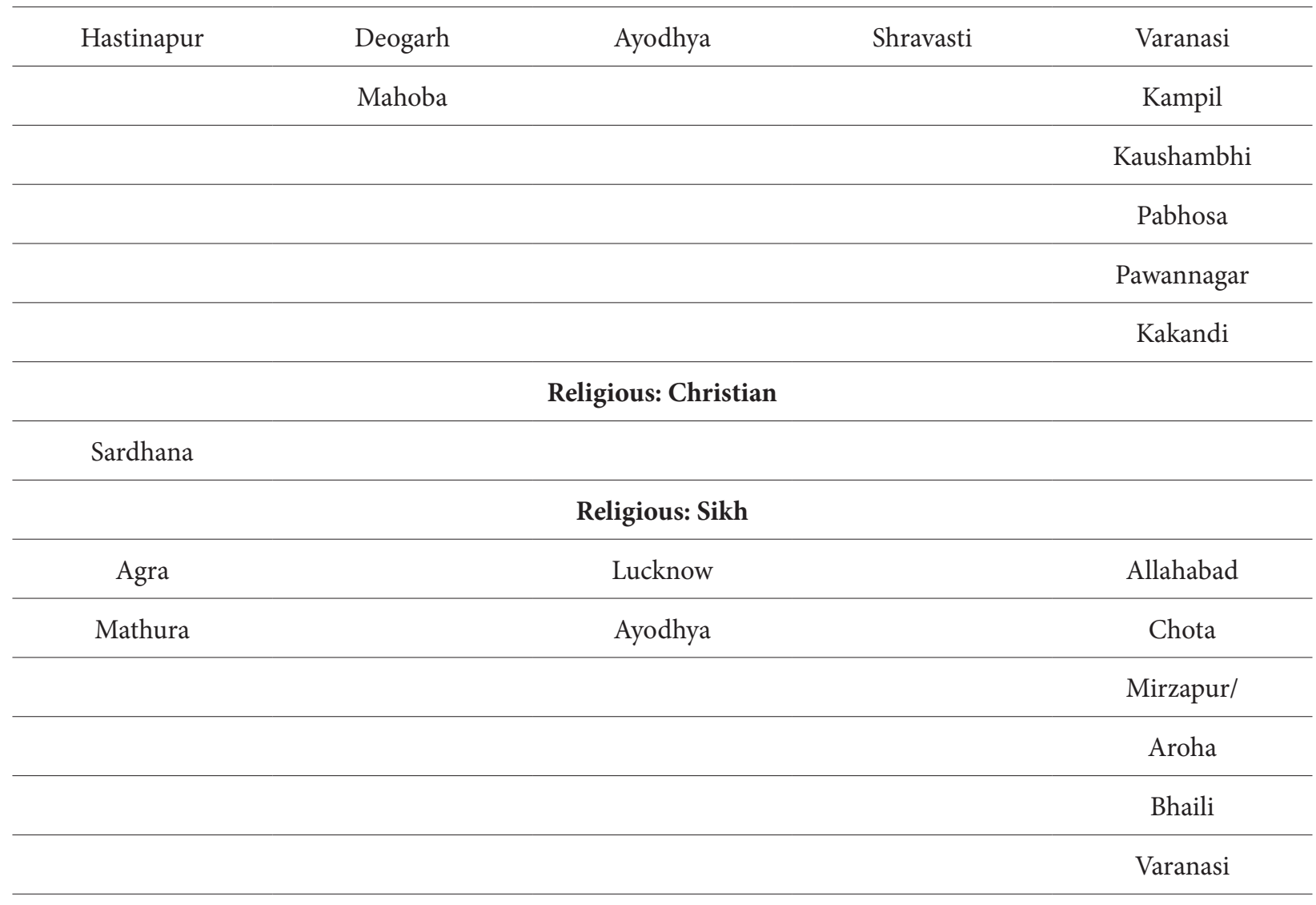

A government report on 20 years perspective plans for Uttar Pradesh, (2002) 
Uttar Pradesh is home to pilgrimage sites for Hindus, Buddhists, Jains, Muslims and Sikhs. The state is characterized by a unique combination of religious and communal harmony. Religious sites are located in diverse parts of the state.

\section{LITERATURE REVIEW}

The word pilgrimage is used in the three varieties (Crim, 1981). Firstly, as an 'internal pilgrimage', 'soul travel'. Secondly, pilgrimage to a holy place, as a form of faith itself. This trip can exactly be called 'extroverted spirituality.' Finally, local pilgrimage which drives evolvement and familiarity of the sacred and the new community. These definitions deliver only theoretical significance of pilgrimage, not distinguishing pilgrimage from different kinds of tourism. Kamil (2000) claims that tourists who consider religious tourism destinations wish to deepen their religious understanding. Their purpose of visit is not to see, but to join and share; to live the past and the present and not be restricted to just sightseeing and picture-taking. Kreiner and N. Kliot (2000) state that the connection between tourism and religion concentrates on the similarity factors, along with differences between the tourist and the pilgrim. Mehta and R. S. Arora (2000) in their article titled, "Tourism Industry in Punjab - an Appraisal of Promotional Activities" have highlighted that the 41 advertisement expenditure share in total management expenses has decreased. Marketing of faith could be understood as an immoral activity of creating money by selling belief and religion. It could be called commodification (Hill 2008; Olsen 2003; Goulding 2000)

S.C. Woodward (2004), in his article "Faith and Tourism", pointed out that the revenue produced by religious sites could be utilized for restoration and preservation of religious places. It is also highlighted that many renowned religious sites of the world are incapable of providing accommodation to enormous number of tourists at one time, which may initiate various problems like overcrowding, accidental damages, theft incidents, littering and parking problems. The author has suggested several solutions, like charging for vehicle access, entry fees to religious sites and so on, in order to overcome the above mentioned problems. Bar and $\mathrm{K}$. Hattab (2003), in their study "A New Kind of Pilgrimage: 19th Century and Early 20th Century Palestine", have indicated that tourism and pilgrimage tourism are sharing a wide range of journeys. They have highlighted five motivation factors, duration, religious affiliation, social background, traveller's reaction and services utilized by tourists, which differentiate pilgrims from tourists. Motiram (2007), in his study "Globalization: Potentials and Prospects of Mass Tourism in India", has defined the effect of globalization on mass tourism in India, that is, Beach Tourism, Mountain Tourism, and Religious Tourism. Gupta (2007) underlined that among several tourism sectors, pilgrimage tourism can reach the objective of sustainability, as its arrangements have naturally less burden on the environment, killing of animals is mostly prohibited, local communities are involved to a large extent, and cultural differences between the guest and the host are significantly less, and it occurs or performs during certain periods in a year. Pilgrimage tourism in India has been practiced since time immemorial. It is the area which is blessed by various scholars (gurus) for spiritual enlightenment (Gupta, 2007). N. Rajasulochana (2008), in her article "A Critical Review of Rural Tourism Policy in Tamil Nadu Context", has observed that most of the ongoing schemes, as well as proposed schemes in Tamil Nadu, are concentrating only on religious sites, thus reinforcing 'temple' tourism rather than rural tourism. Rakesh Premi (2010), in his study "Brand Pushkar (Destination Branding on the Planks of Culture and Religious Heritage as USP)", has found that there is no significant promotion or advertisement within and outside the country for tourism. Venkatachalam \& Patwardhan (2011) emphasized that numerous places in India are struggling at present with complications related to sustainable growth of pilgrimage tourism, like conservation and environmental management and cultural tourist assets, as well as protection \& safety of tourists.

\section{RESEARCH OBJECTIVES}

- To analyze the prevailing marketing tools and find the marketing area to focus in order to reach the target customers;

- To identify several economic dimensions in pilgrimage tourism.

\section{Areas of study}

India is known as the land of temples and religions. Uttar Pradesh, known as the United Provinces before the independence, is the most populous state with the population higher than the combined population of some West European nations (Sajnani, M., 2001). It is full of religious places with temples that attract pilgrims and religion enthusiasts throughout the year. The cities and towns in Uttar Pradesh are not just popular on the account of the temples and pilgrims, but also for their beautiful geography. 


\section{Research Design}

The research paper is primarily grounded on the secondary data, such as brochures, pamphlets, books, newspapers, internet, advertisement etc.

\section{Marketing perspective of religious tourism}

Government Measures: Prevailing Marketing Tools

The biggest USP of India is that it can provide guidance to help achieve inner peace. Uttar Pradesh Tourism Corporation has circulated literature, which includes all information about religious places, at nominal cost. The following list can explain the marketing strategy to reach target customers for tourism in Uttar Pradesh:

- The use of Government measures by the wider community not just as the development route, but also as a marketing strategy for revenue generation;

- The conservation of worship places of historic value, for enhanced experience of targeted tourists.

Module I: Digital and Infrastructure

- Digital Marketing: www.uptourism.gov.in;

- Reservation of accommodation, such as hotels, lodges, and their tariffs are also available on the website; Bookings can be made at the Advance Reservation Centres;

- The Department is trying to offer lodgings at reasonable tariffs;

- Complaint Lodge centre at Regional Tourist Offices;

- In order to reassure tourists and to build their confidence in relation to safety and security, Uttar Pradesh Tourism, with the help of the Police Department, has started tourist police service at major places like Varanasi, Agra etc;

- Circuit Development Committees;

- Awareness campaigns had been launched in the major tourist places of the state with the help of NGOs and Travel Trade;

- Overseas marketing for Uttar Pradesh tourism had been reoriented with the help of the Government of India; Tourist offices abroad; Publicity material on U.P. tourism had been published in foreign languages and distributed through these offices;
- Uttar Pradesh tourism: Special sessions are arranged with the representative of CII, ASSOCHAM and FICCI to make investors aware of available incentives;

- Special projects launched for sustainable infrastructure improvement in the Vindhyachal region, Chitrakoot region, Bundelkhand and Ayodhya region;

- An International Travel Writer's convention had been organized in Uttar Pradesh;

- Computerization and web-based networking of all UPT offices, Tourism Site Offices;

- Digitalization of all visual sources of monuments, tourist sites, and attractions.

\section{Module II: Financial Outlook}

- The state budget of Uttar Pradesh increased by 10.2 per cent in 2015-16 as compared with the budget in 2014-15. In 2015-16, the state government proposed an investment of US\$ 50,333.3 million. The investment planned for overall tourism development has been estimated at Rs. 3460 crores (at current prices) for the 20 year period. (Total investment for Varanasi 93455 lakh; for Allahabad 1355 lakh; for Buddhist Circuit 97397 lakh; for Mathura Vrindavan 6710 lakh (2014-15).

\section{Module III: Changing Destination Image}

Religious cultural tourism does not only provide pilgrimage travel facilities for religious devotees, but also offers activities for ordinary people to comprehend, touch and identify religious culture (Nyaupane, Timothy and Poudel, 2015).

- Creating Heritage Arc Circuit;

- Special packages for religious tourism: from organizing travel to reservation of accommodation, companies offer several facilities to make the holiday in Uttar Pradesh a flourishing and pleasing experience;

- Reinforcement and progression of local facilities and services;

- Foundation of Tourist Facilitation Centres: it is to be set up in various places like Mathura and Vrindavan etc. with centralized booking and complain resolution framework;

- Experience through Expos: to explain the history of the temples and places, its significance and its importance to the present society;

- Science and Spirituality Pavilion: an interactive exposition space, to stimulate an investigative attention about the thoughtful theoretical phenomenon; 
- Motivating speakers and preachers: to spread spirituality and educate about history of religious places, like Swami Ramdev, Murari Babu, etc;

- Connecting worldwide: link temples with International Societies worldwide, to promote destinations like Iskon.

Module IV: Fairs and Festivals - creating sources of attraction

- Uttar Pradesh has traditional religious and state festivals which are organized in various places like Allahabad, Varanasi, Mathura, Agra etc. For fascinating travellers, government is celebrating fairs and festivals every year, like Magh Mela conducted at Prayag, on the banks of Triveni Sangam, which involves Ganga, Yamuna and Saraswati, some other festivals like Dev Deepawali Festival, Laththmar Holi (Barsana), Deva Sharif Mela (Barabanki) and every twelfth year, the Magh Mela is transformed into the Kumbh Mela. The administration and security measures are organized by the local government. The Mela is exclusively distinguished for the existence of an amazing array of religious saints and devotees.

\section{Religious / pilgrim Centres \& Circuits}

UP, as a state, has a diversified range of "tourism assets" that can be developed and promoted. The state can hence attract a wide range of tourist profiles (both domestic and international of various budget groups).

- Buddhist circuit; Kushinagar, Kapilvastu, Sravasti, Sankisa, Sarnath;

- Bundelkhand circuit; Jhansi, Khajuraho, Deogarh;

- Braj (Agra-Mathura) circuit; Mathura Vrindavan;

- Awadh circuit; Ayodhya, Bhratkund, Allahabad;

- Varanasi circuit.

\section{ECONOMIC DIMENSIONS OF RELIGIOUS TOURISM}

Indian Ministry of Tourism in 2002, in the survey on domestic tourism, conveyed that approx.100 million tourists journeyed for religious experience and pilgrimages. The survey highlighted top ten national tourists' destinations. The Satellite accounts recorded that religious tourism contributed with $20 \%$ to the entire domestic tourism consumption (approximately INR 2.8 billion). On this account, many different authors have attempted to define it, and it forms part of multidisciplinary studies. The economic impact assessment can trace the changes of economic activity. This will lead to the estimation of economic sectors taking advantage of tourism industry, such as employment. Religious tourism is the mixture of traditional tours to shrines and cultural trips designed, guided and synchronized by religious organizations or for religious purposes. The Ministry of Tourism collects the statistics of foreign exchange earned through foreign tourists. The Ministry does not compile the data of earnings related to domestic tourists. The Foreign Exchange Earnings (provisional) through Tourism in India during 2012, 2013, 2014 and 2015 were Rs. 94,487 Crore, Rs. 1, 07,671 Crore, Rs. 1,23,320 Crore, and Rs. 1,35,193 Crore, respectively. The Associated Chambers of Commerce and Industry of India (Assocham), UP along with Tamil Nadu, Maharashtra and Delhi have categorized the most popular tourist destinations in the survey Realizing Tourism Potential of UP. Uttar Pradesh has the potential to fascinate above 2.8 million foreign tourists by 2017 , compared to over 2 million overseas backpackers in 2013. Looking compounded annual growth rate (CAGR) of $8 \%$, UP fascinated over 2.05 million foreign tourists in 2013 and ranked fourth with $10 \%$ share in the total inflow of roughly 20 million foreign tourists visiting India. Some religious sites like Agra (59\%), Allahabad (18.5\%) and Sarnath (17\%) are the most visited destinations by foreign tourists in UP. Buddhist tourism is spread, as UP is home to places like Sarnath, Kushinagar, Sankasia, Kaushambi and Sravasti, which attracted 2.7 million tourists in 2013, growing at CAGR of 5\%. It is estimated to rise to 3.3 million by 2017 (Singh Rawat, 2015). According to statistics of the Ministry of Tourism, in 2013, top 10 states in domestic tourist visits were Tamil Nadu, Uttar Pradesh, Andhra Pradesh, Karnataka, Maharashtra, Madhya Pradesh, Rajasthan, Gujarat, West Bengal and Chhattisgarh. Average per day Domestic Tourism Expenditure per tourist, by state of destination, for visitors from other states is 689 . The least domestic expenditure, per traveller daily, was declared in the case of Uttar Pradesh (Rs. 234) (NCAER, 2015). 


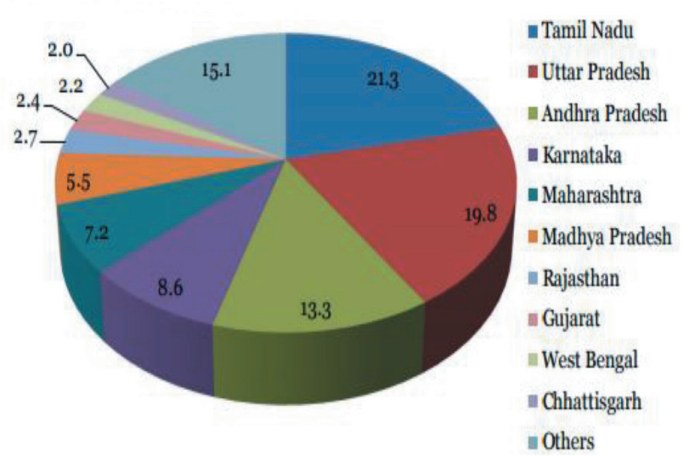

Fig. 1. Top-ten ranking Pilgrimage Sites

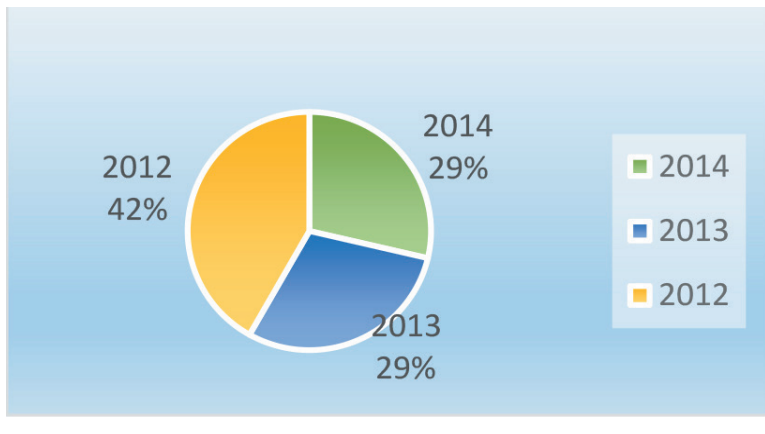

Fig. 2. Growth of Foreign Tourist visit (FTVs)

Table 2. Domestic tourist expenditures

\begin{tabular}{cccccccccc}
\hline State & Business & $\begin{array}{c}\text { Leisure } \\
\text { and } \\
\text { creation }\end{array}$ & Social & Religious & $\begin{array}{c}\text { Education } \\
\text { and } \\
\text { training }\end{array}$ & $\begin{array}{c}\text { Health } \\
\text { and } \\
\text { Medical }\end{array}$ & Shopping & $\begin{array}{c}\text { Other } \\
\text { Purposes }\end{array}$ & $\begin{array}{c}\text { All Pur- } \\
\text { poses }\end{array}$ \\
\hline $\begin{array}{c}\text { Uttar } \\
\text { Pradesh }\end{array}$ & 76565 & 119623 & 2725786 & 321693 & 39787 & 430068 & 31519 & 131147 & 3876187 \\
\hline
\end{tabular}

Source: NCAER computation using 65th round NSSSO Report

\section{Tourist Traffic Forecasts:}

The aggregate conservative forecast has been assessed for the whole of UP over the next 20 years period. The pilgrim category represents primarily the domestic low income mass pilgrim segment, which is less constrained by the lack of adequate infrastructure. Tour operators of various regions were surveyed at the sites and they pointed out that the elasticity of visits for the non-pilgrim category, in relation to the proposed projects and facilities' building as per the perspective plan, is considerably higher than for the domestic mass pilgrim segment.

\section{Physical Infrastructure:}

A total amount of about US $\$ 4.29$ billion has been allocated for the upgradation and line maintenance of the state power sector. The state government is targeting to increase the power generation to 2,100 MW by the end of 2016. The ongoing Lucknow metro project has been allocated with US\$ 70.8 million to build up the system of state transportation. The Lucknow Agra Express way is allocated with US $\$ 500$ million to make it India's longest elevated express way.

Table 3. An overview of available Infrastructure

\begin{tabular}{llll}
\hline $\begin{array}{l}\text { Installed power capacity } \\
\text { (MW) }\end{array}$ & $15,721.8$ & $282,023,39$ & Central Electricity Authority \\
\hline Wireless subscribers (No) & $138,507,350$ & $1,003,487,792$ & $\begin{array}{l}\text { Telecom Regulatory Authority of India, } \\
\text { as of October 2015 }\end{array}$ \\
\hline Internet subscribers (No) & $19,170,000$ & $319,420,000$ & $\begin{array}{l}\text { Telecom Regulatory Authority of India, } \\
\text { as of June 2015 }\end{array}$ \\
\hline $\begin{array}{l}\text { National highway length } \\
(\mathbf{k m})\end{array}$ & 7,863 & 96,214 & NHAI \& Roads and Building Department \\
\hline Airports (No) & 6 & 125 & Airports Authority of India Airports \\
\hline
\end{tabular}

Press Information Bureau, Ministry of Tourism (2016, March) 


\section{Assessment of threats and opportunities}

Religious tourism, as a sector, is not well explored and recognized. The following table is based on available literature and it depicts the threats and some opportunities for religious tourism industry.

\section{CONCLUSION}

The paper observed the interconnection between pilgrimage tourism, economic activity and opportunities for development. Tourist sector should focus on improvement and application of marketing strategies, according to the marketing mix elements, which will lead to satisfaction of tourists and more visits to tourist destinations. This paper has addressed underresearched aspects of religious tourism. Therefore, it is vital that the tourism marketing plan is created in tune with authorities from public or private sector. The paper observed that religious sites should play an active role in the growth of targeted tourists and the improvements on their territory. For further research, the study intends to open the door for religious events and religious tourism promotion.

Table 4. Threats and Opportunities Analysis of Pilgrimage Destinations

\begin{tabular}{|c|c|}
\hline Immediate Action Required: Threats & Future perspective: Opportunities \\
\hline $\begin{array}{l}\text { - Cleaning and maintenance of the ghats; } \\
\text { washrooms for men and women; } \\
\text { - Cafeteria / refreshment shops at the ghats; } \\
\text { - Hygienic restaurants in the main mandir areas; } \\
\text { - } \text { - Skill building programs are required; } \\
\text { - Development of the air strip present in Ayodhya for } \\
\text { chartered flights or helicopter facilities; } \\
\text { - Chartered flights or helicopter facilities connect- } \\
\text { ing to Chitrakoot and Sitamarhi for ease of high-end } \\
\text { tourists of the circuit; } \\
\text { - Star \& deluxe hotels for high end travellers; } \\
\text { Direct train connectivity with Chitrakoot; } \\
\text { Direct bus connectivity with Chitrakoot, Sitamarhi \& } \\
\text { Janakpurdham; } \\
\text { - Coordination between Tourism Department and other } \\
\text { direct tourism promotion agencies such as Culture, } \\
\text { State Archaeology, ASI, and Forests/Horticulture; } \\
\text { Unavailability of proficient tourist guides; } \\
\text { ble elements; }\end{array}$ & $\begin{array}{l}\text { To strengthen religious tourism in UP, the central } \\
\text { government in } 2016 \text { allowed projects worth over Rs } 300 \\
\text { crore related to pilgrimage circuits; } \\
\text { Uttar Pradesh government will create a new act un- } \\
\text { der the tourism policy in } 2017 \text {. The Principal Secretary } \\
\text { for Tourism Navneet Sehgal said that the new act will } \\
\text { be adopted for the security of tourists in the state and } \\
\text { saving them from any types of mistreatment and } \\
\text { manipulation. The institutionalization of this act may } \\
\text { attract more tourists towards Uttar Pradesh; } \\
\text { As per budget 2015-16, the Government of Ut- } \\
\text { tar Pradesh announced plans to invest US\$ } 2.02 \\
\text { billion for construction of roads and bridges and } \\
\text { implementation of special schemes for Purvanchal and } \\
\text { Bundelkhand; } \\
\text { Need for prioritization and determining focus } \\
\text { locations for promotion that can serve as "leading } \\
\text { destinations", which will provide critical mass to "pull" } \\
\text { tourism; } \\
\text { Categorize and improve niche tourism products; } \\
\text { Promote private sector to participate proactively. }\end{array}$ \\
\hline
\end{tabular}

\section{REFERENCES}

Bar, D., \& Hattab, K. (2003). A New Kind of Pilgrimage: The Modern Tourist Pilgrim of Nineteenth Century and Early Twentieth - Century Palestine. Middle Eastern Studies. 39, 131-148.

Collins-Kreiner, N. \& Kliot, N. (2000). Pilgrimage Tourism in the Holy Land: The Behavioural Characteristics of Christian Pilgrims. Geo Journal. 50, 55-67.
Crim, K. (1981). Abingdon dictionary of living religions. Nashville: Abingdon.

Hill, B. J. (2002). Review of: Tourism and religion, by Boris Vukonic. The International Journal of Tourism Research. 4, 327-328.

Kelly, C. and Smith, M. K. (2009) Holistic tourism: integrating body, mind and spirit. In: R. Bushell and P. Sheldon, (eds) Wellness and Tourism: Mind, Body, Spirit, Place. Cognizant, New York, pp. 69-83. 
Mehta, A., \& Arora, R. S. (2000). Tourism Industry in Punjab - An Appraisal of Promotional Activitie. Indian Management Journal. 4, 91-102.

NCAER. (December 2015). Statewise comparison of characteristics of domestic trips in India. Domestic Tourism Survey Commissioned by Ministry of Tourism, Government of India. Retrieved May 13, 2017 from http://tourism.gov.in/sites/default /files/Other/State-wise\%20Report_Final_\%2829 -12-15\%29.pdf

Nyaupane, G. P., Timothy, D. J., \& Poudel, S. (2015). Understanding Tourists in Religious Destinations: A Social Distance Perspective. Tourism Management. 48, 343-353.

Rajasulochana, N. (2008). A Critical Review of Rural Tourism Policy in Tamil Nadu Context. TourismA Catalyst for Economic Development Seminar Volume. Department of Commerce and History, Christian College: Guntur, Andhra Pradesh. 36-37.
Rakesh, P. (2010). Brand Pushkar (Destination Branding on the Planks of Culture and Religious Heritage as USP). Indian Journal of Marketing. 40, 23-28.

Singh Rawat, V. (March 11, 2015). UP foreign tourist arrival may cross 2.8 mn by 2017. Retrieved May 13, 2017, from http://www. business-standard.com/ article/current-affairs/ up-foreign-tourist-arrivalmay-cross-2-8-mn- by-2017-115031100678_1.html.

Venkatachalam, V. B., \& Patwardhan, V. (2011). Sustainable Religious Tourism Destination Management: The Case of Udupi, India. In P. S. Manhas, (Ed.). Sustainable Destination Excellence: Innovations in Alternative Tourism. (pp. 44-53). SHTM, University of Jammu: Jammu \& Kashmir.

Woodward, S. C. (2004). Faith and Tourism: Planning Tourism in Relation to Places of Worship. Tourism and Hospitality Planning and Development. 1, 173-186. 